\title{
Technical Notes on Acrylamide Gel Electrophoresis Used for Comparing Isozymes of Mosquito Larvae*
}

\author{
Masuhisa Tsukamoto \\ Department of Medical Zoology, School of Medicine, University of \\ Occupational and Environmental Health, Japan. Kitakyushu 807, Japan
}

\begin{abstract}
Various slight modifications of electrophoretic techniques were tried to obtain more reproducible results for comparing several isozymes with individual mosquito larvae. Horizontal electrophoresis was done using polyacrylamide gel plates of $1 \mathrm{~mm}$ thickness on a simple cooling system in which ice-cold water was circulated. This made it possible to carry out electrophoresis effectively even during field work in tropical areas. Gel concentration in routine work is $5 \%$ for usual enzymes, but for esterase, $6 \%$ gels have been adopted. Gel concentrations, running distance, running time, visualization of isozyme bands, etc., have especially been considered.
\end{abstract}

Key words: isozyme, electrophoresis, acrylamide gel, mosquito larva.

(Received 15 February 1984)

\section{Introduction}

A biochemical approach has been tried to understand the phylogenic relationship of mosquitoes of Japan, the Philippines and Thailand, sometimes in a laboratory and sometimes in field circumstances especially in tropical local areas where no city electricity is available. Under such a condition the use of a portable generator, a portable centrifuge, a small water-circulator, a simple DG power supplyer, etc. was quite effective in carrying out electrophoretic analysis of mosquito larvae even at the most isolated villages in mountain areas.

Although recipes on special staining methods for starch gel electrophoresis were compiled by Shaw \& Prasad (1970) and Steiner \& Joslyn (1979) also described electrophoretic techniques for mosquito study, much technical information is scattered in various papers and details of the most important technical tricks or secrets are usually not written in original papers.

Some parts of the techniques explained here are largely based on modifications of the method of Ogita (1965) and already described in previous papers (Tsukamoto, 1974,

\footnotetext{
* This investigation received partially Grants-in-Aid for Special Research Promotion; for Overseas Scientific Survey; and for General Research $(\mathrm{C})$; from the Ministry of Education, Science and Culture, Japanese Government: Project No. 57123117 entitled "Fundamental Studies on the Control of Tropical Parasitic Diseases"; Project No. 58041058 entitled "Phylogenic Studies on Mosquito Fauna of Thailand"; and Project No. 58570191 entitled "Phylogenic Comparison of Isozymes in Japanese Mosquitoes", respectively.
} 
1982). Further additional modifications have been attempted to obtain much simpler and easier but reliable and reproducible procedures, especially which can be performed even under tropical field environments. The purpose of the present paper is to describe the detailed techniques used for biochemical comparison of Asian mosquito larvae, so that even a beginner can easily adopt the techniques in polyacrylamide gel electrophoresis. Actual results obtained from our investigations will successively be published soon elsewhere.

\section{Comparison of Electrophoretic Conditions}

1. Preparation of gel plates

By mixing stock solutions $\mathrm{A}, \mathrm{B}$, and $\mathrm{C}$, gels of an appropriate concentration of acrylamide can be prepared. Since a $5 \%$ gel has been used in routine experiments, the following examples are mostly based on the $5 \%$ gel concentration:

A. Stock solutions

1) Solution A :

Acrylamide (monomer)

$19.0 \mathrm{~g}$

$N, N^{\prime}$-Methylenebisacrylamide (BIS)

$1.0 \mathrm{~g}$

Distilled water

to

$200 \mathrm{ml}$

2) Solution B : Tris(hydroxymethyl)aminomethane (Tris)

$9.12 \mathrm{~g}$

$1 \mathrm{~N} \mathrm{HCl}$

$12.0 \mathrm{ml}$

TEMED

$1.0 \mathrm{ml}$

Distilled water

to $\quad 100 \mathrm{ml}$

3) Solution $G$ : Ammonium persulfate (APS)

$50 \mathrm{mg}$

Distilled water

$50 \mathrm{ml}$

The solutions $\mathrm{A}$ and $\mathrm{B}$ can be kept up to 3 months, if necessary, in cool and dark conditions. In the case of solution $\mathrm{C}$, it is desirable to prepare a fresh solution each time, but according to my experience the solution can practically be used within $5-6$ days without the loss of effect if kept in a refrigerator. A large bottle of APS (for example, $500 \mathrm{~g}$ ) is not expensive, but do not buy such a large bottle because the aged chemical frequently loses its trigger effect on polymerization of the gel, and I would recommend to buy the smallest of commercially available packs (for example, $1 \mathrm{~g}$ ). Since esterase activity is easily inhibited by excess amounts of APS, do not use larger amounts of APS than described here.

B. Working solution for $5 \%$ gels

For preparing the standard $5 \%$ gel, mix the solutions $\mathrm{A}, \mathrm{B}$, and $\mathrm{C}$ in the proportion of $2: 1: 1$, respectively. Solutions $\mathrm{A}$ and $\mathrm{B}$ can be mixed together but solution $\mathrm{C}$ should 
Table 1. A chart for preparing different concentrations of gels by mixing the standard solutions

\begin{tabular}{cccc}
\hline Gel concentration & Solution A & Solution B & Solution C \\
\hline $5.0(\%)$ & $12(\mathrm{ml})$ & $6(\mathrm{ml})$ & $6(\mathrm{ml})$ \\
5.5 & 16 & 8 & 5 \\
6.0 & 16 & 8 & $3^{*}$ \\
\hline
\end{tabular}

* Twice concentrated solution $\mathrm{C}$ should be used.

Table 2. A chart for preparing different concentrations of gel by changing components of the solution A

\begin{tabular}{lrrrrrrrr}
\hline Component & $4 \%$ & $4.5 \%$ & $5 \%$ & $5.5 \%$ & $6 \%$ & $6.5 \%$ & $7 \%$ & $7.5 \%$ \\
\hline Acrylamide & 7.6 & 8.55 & 9.5 & 10.45 & 11.4 & 12.35 & 13.3 & $14.25(\mathrm{~g})$ \\
BIS & 0.4 & 0.45 & 0.5 & 0.55 & 0.6 & 0.65 & 0.7 & $0.75(\mathrm{~g})$ \\
Dist. water & to 100 & 100 & 100 & 100 & 100 & 100 & 100 & $100(\mathrm{ml})$ \\
\hline
\end{tabular}

be mixed immediately before pouring the working solution. After thorough mixing, the working solution can be poured onto a framed plate (degassing is not necessary), then cover the solution with a plastic plate, and wait for at least one hour for complete polymerization of the gel (during this period one can prepare samples for electrophoresis). Avoid leaving any small air bubbles because they will develop into a bigger hole in the gel after polymerization.

The size of gel plates routinely used in our laboratory is about $15 \mathrm{~cm} \times 10 \mathrm{~cm} \times 1$ $\mathrm{mm}$. For this size, a mixture of $12 \mathrm{ml}: 6 \mathrm{ml}: 6 \mathrm{ml}$ of solutions $\mathrm{A}, \mathrm{B}$, and $\mathrm{C}$, respectively, is suitable.

C. Working solution for other concentration gels

For preparing other concentrations of gels than $5 \%$, one can use the same solutions $\mathrm{A}, \mathrm{B}$, and $\mathrm{C}$ by changing the mixing proportions. Table 1 gives actual examples of the mixing proportion of each solution for making various concentrations of the gels. However, only in the case of $6 \%$ gel, should the concentration of solution $\mathrm{C}$ be twice that of the standard solution $\mathrm{C}$ because of its small volumes of the solution: i.e., 50 $\mathrm{mg}$ APS in $25 \mathrm{ml}$ distilled water, instead of the usual $50 \mathrm{ml}$.

Another method to make various concentrations of gels is to prepare various concentrations of solution A. Table 2 gives actual examples for preparing various concentrations of solution A.

2. Electrode buffer

The following buffer can be used as a standard electrode buffer where $\mathrm{pH}$ value is about 8.3 : 
Boric acid

$\mathrm{NaOH}$

$2.4 \mathrm{~g}$

Distilled water

to $1000 \mathrm{ml}$

This solution can be kept for a long time at usual room temperature. The time necessary for an electrophoretic run is about 1.6 hours under routine conditions. After about 10-15 electrophoretic runs the electrode buffer should be changed to the fresh solution.

The electrophoretic patterns obtained by using a diluted electrode buffer are similar to those obtained by using the original electrode buffer, but the time required for the run is quite a bit longer than routine runs. For example, a 10 times dilution of the original buffer solution resulted in a $4 \mathrm{hr}$ run instead of the usual $1.5 \mathrm{hr}$. In a previous paper, 1974, the concentration of $\mathrm{NaOH}$ was misprinted as $0.05 \mathrm{M}$. When $0.05 \mathrm{M} \mathrm{NaOH}$ is adopted in this solution the $\mathrm{pH}$ value will be about 8.0 and separation of isozyme bands is not so good. Furthermore, the time necessary for an electrophoretic run is much longer than that for the standard $0.06 \mathrm{M} \mathrm{NaOH}$ recipe.

\section{Preparation of mosquito samples}

An individual 4th-instar larva was homogenized with distilled water by hand in an ice-bath or at room temperature (about $15-27^{\circ} \mathrm{C}$ in the laboratory in Japan, and about $25-33^{\circ} \mathrm{C}$ in tropical or subtropical zones). Sometimes, individual larva was further dissected under a stereomicroscope into several body parts such as head, thorax, abdomen, and/or digestive tract. It was learned through that different amounts of distilled water are necessary for homogenizing a larva of different species. For example, depending upon enzyme activity to be detected, $20 \mu \mathrm{l}$ to $30 \mu \mathrm{l}$ for a larva of usual size and $75 \mu \mathrm{l}$ to $200 \mu 1$ for a Toxorhynchites larva. As a rule, fresh samples are prepared each time, but supernatants or homogenates kept for a few days in a refrigerator can also be used to detect leucine aminopeptidase (LAP) or malic enzyme (ME) without remarkable loss in the enzyme activity of various mosquito larvae.

A hematocrit centrifuge (Tomy, RC-24BN) is used to obtain supernatants from homogenates at $11,000 \times \mathrm{g}$ for $5 \mathrm{~min}$ routinely in the laboratory, but in field work where no city electricity is available, a dry-battery driven portable centrifuge (Minizentrifuge COMPUR M1100) is effectively used at about $5,000 \times \mathrm{g}$ for $6 \mathrm{~min}$.

\section{Electrophoresis}

Any equipment for electrophoresis can be utilized, but commercially available tools are usually too large, too heavy, and too expensive; size and/or shape of electrode vessels are also too deep or too wide, and some equipments have no cooling system attached. Such instruments are inconvenient especially for overseas research. Therefore, a compact electrophoresis apparatus with a simple cooling system has been designed by me (Fig. 1 ). Each $100 \mathrm{ml}$ electrode buffer can be poured into each vessel. Horizontal electrophoretic 

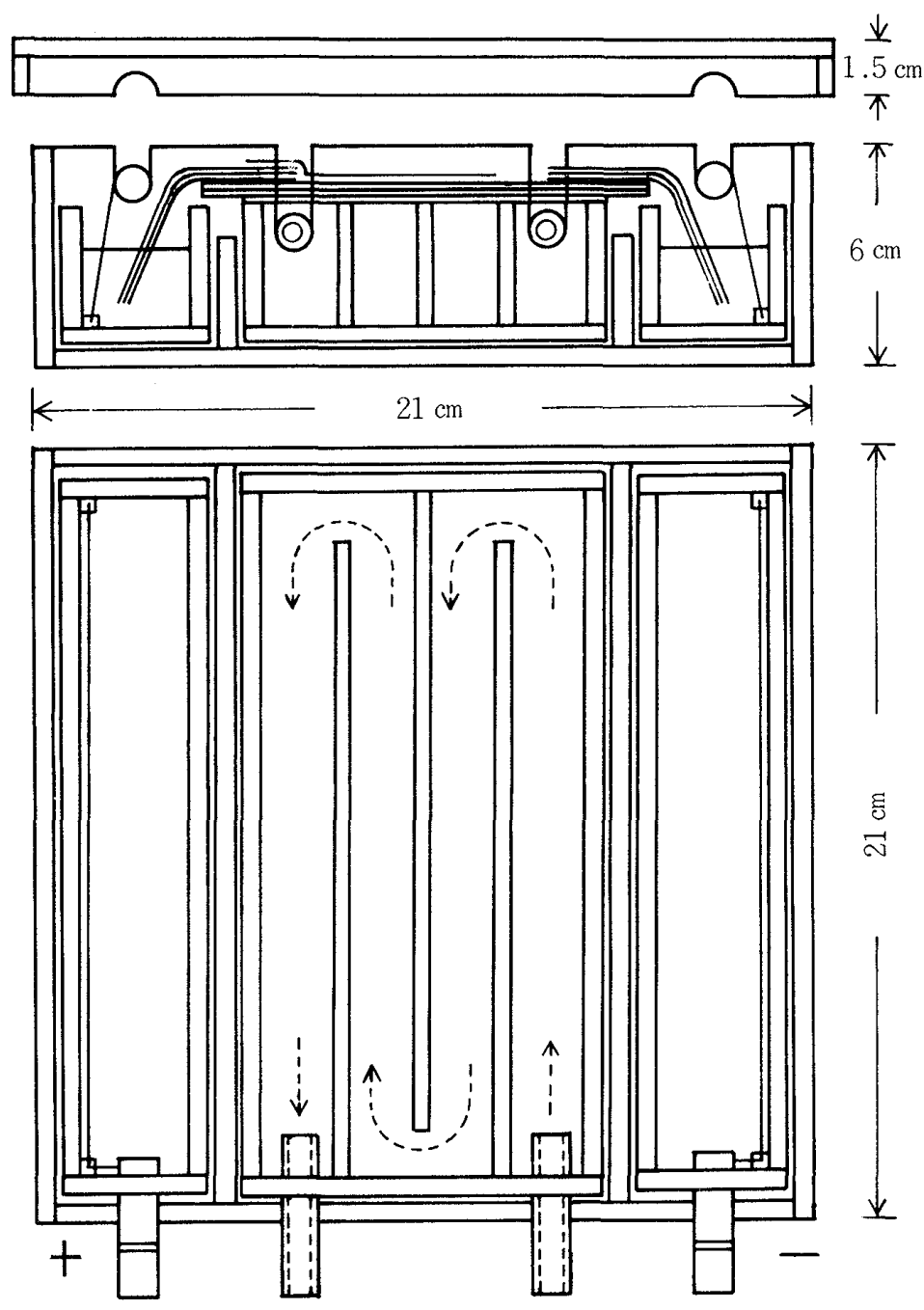

Fig. 1. Design of the electrophoretic apparatus. Upper: Cross section and front view. Lower: Top view. The plastic apparatus consists of 5 independent parts : a cooling unit, two electrode vessels, a container, and its cover. Two sheets of filter paper bridge are further covered by a sheet of Parafilm.

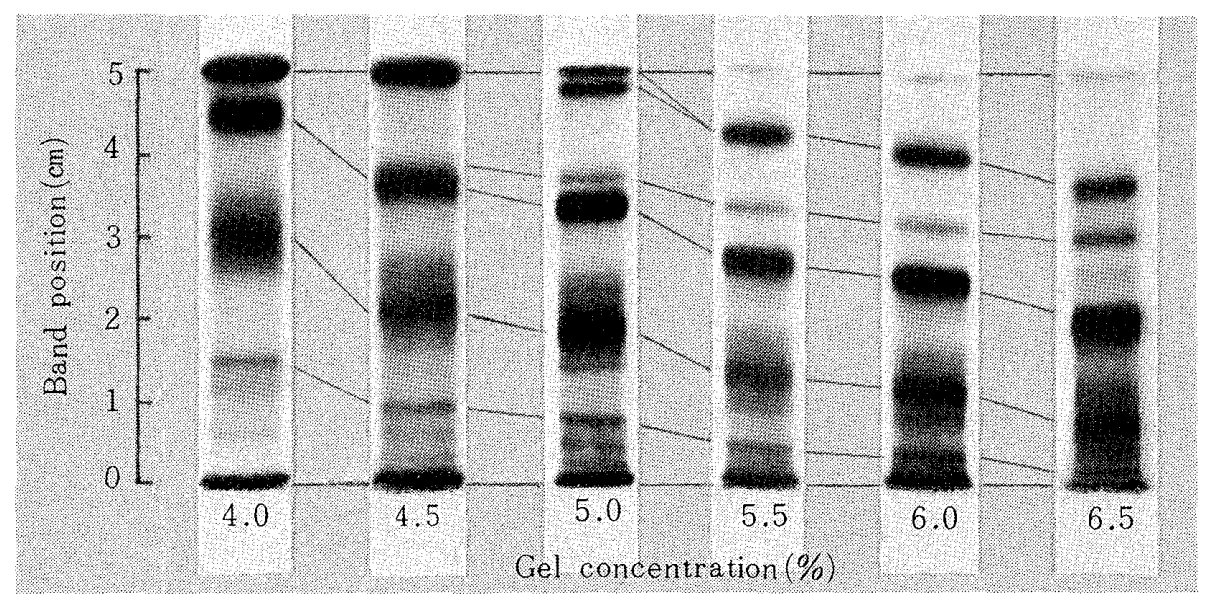

Fig. 2. Examples of zymograms for examining effect of gel concentrations on migration and separation of LAP isozyme bands of Aedes aegypti larva. 
runs are performed at a constant DC power gradient of $20 \mathrm{v} / \mathrm{cm}$ on a cooling stage in which ice-cold water is circulated by a small water pump, thus it is not necessary to carry out electrophoretic runs within a refrigerator. A portable generator, Honda $300 \mathrm{~W}$, can be used as an electric source in field research. This makes it possible to carry out experiments during field work, even in tropical or subtropical rural areas.

\section{Gel concentration}

Search for suitable concentration of acrylamide in gel was done by varying the concentration from $4 \%$ to $6.5 \%$. In the cases of $4 \%$ or $4.5 \%$, the gels were too soft and easily breakable during handling, staining, washing and preserving the gels. On the other hand, the $6.5 \%$ gel is harder and easier to handle, but the time necessary to perform an electrophoretic run is too long (about 2.5 to 3 hours under our experimental conditions), and results on band separation of some isozyme were not as good as from my expectations at higher gel concentrations (Fig. 2). Most of the isozymes can be examined effectively in 5\% gels, and they showed appropriate migration rates (namely, band mobilities are neither too fast nor too slow). In the case of non-specific esterases of some mosquito species, however, a band or some bands moved together with the anionic front when $4-5 \%$ gels were used. In such cases it is impossible to distinguish whether a frontal esterase band consists of only one esterase band or a mixture of more than two bands.

At present, therefore, $5 \%$ gels are used in our laboratory as a standard for various enzymes, but $6 \%$ gels are also used for detection of esterase bands. If it is inconvenient

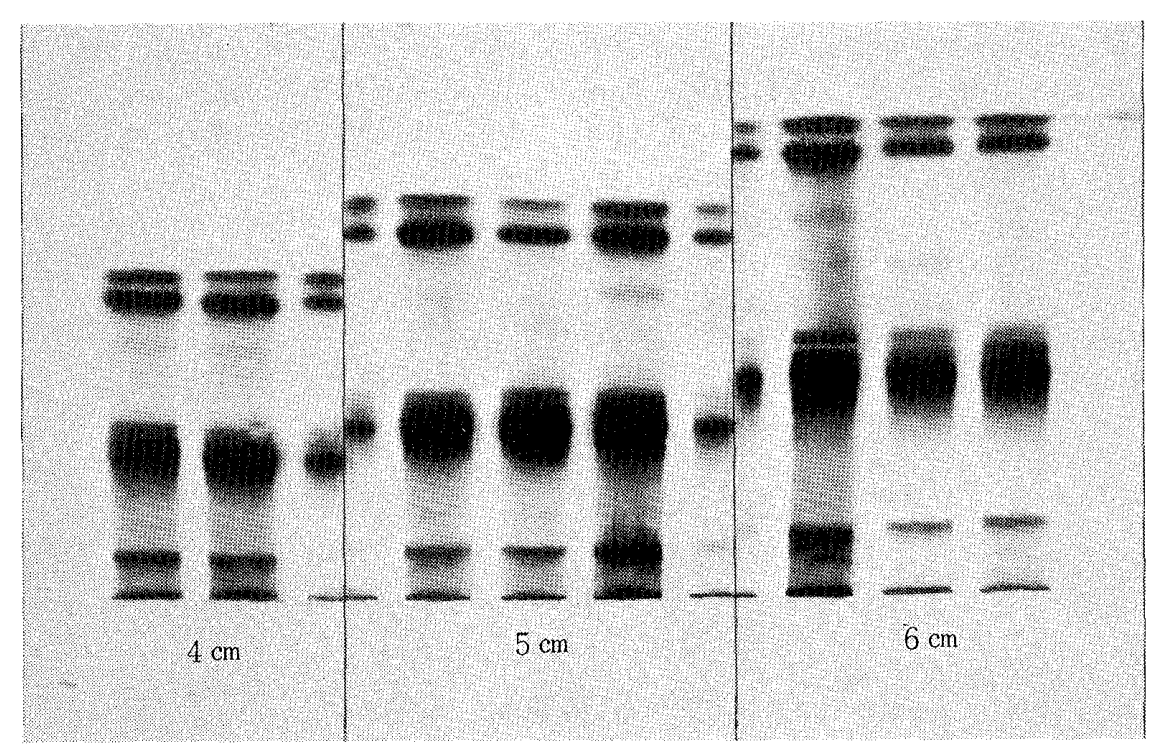

Fig. 3. Examples of zymograms to demonstrate different migration distances $(4,5$ and $6 \mathrm{~cm})$ of the anion front and mobility of each LAP isozyme band in Culex p. quinquefasciatus. Enzyme preparation: $28 \mu \mathrm{l}$ water/larva, Gel concentration: $5 \%$. 
to prepare two different kinds of gels during a field survey, $5.5 \%$ gels may be useful for various enzyme systems including esterases.

\section{Migration distance}

In discontinuous electrophoresis, the anion front will be observed as a visible frontal line together with migration of a melanotic pigment (namely, an oxidative artifact) or an added color indicator (a small piece, about $2 \mathrm{~mm} \times 2 \mathrm{~mm}$, of $\mathrm{pH}$ indicator paper is conveniently used as previously described, Tsukamoto, 1982).

As shown in Fig. 3, the effect of migration distance (from the start line to the anion front) on isozyme patterns was compared by using a $5 \%$ gel on the basis of $4 \mathrm{~cm}, 5 \mathrm{~cm}$, and $6 \mathrm{~cm}$ runs. Namely, one third of a single gel was cut at first when the buffer front reached the $4 \mathrm{~cm}$ mark, and stained for isozyme band detection. Then another one third of the gel was cut when the front line arrived at the $5 \mathrm{~cm}$ mark and removed for detection of band pattern, and the electrophoresis of the remainder was stopped at the $6 \mathrm{~cm}$ line. The absolute migration distance of isozyme bands changed from one gel part to another gel part, but the relative migration rate (i.e., relative mobility) of isozyme patterns was practically unaffected by migration distances. No remarkable improvement of band separation was observed in the case of the $6 \mathrm{~cm}$ run. The time required for a $4 \mathrm{~cm}$ run is about $\mathrm{l} \mathrm{hr}$ and $20 \mathrm{~min}$; for $5 \mathrm{~cm}, 1 \mathrm{hr}$ and $40 \mathrm{~min}$; and for $6 \mathrm{~cm}, 2 \mathrm{hr}$, respectively. Therefore, the $5 \mathrm{~cm}$ run has been adopted as a standard for the routine electrophoresis in our laboratory because calculation or comparison of relative mobilities on separate gel plates is easier in cases of $5 \mathrm{~cm}$ runs.

\section{Preservation of gels}

A stained gel can be preserved as a dried film by sandwiching it between two large sheets of cellophane which have previously been soaked in a $2 \%$ glycerol solution. For drying-up, the sandwiched gel is attached on a glass plate which has been precoated with a thin layer of vaseline. The gradual drying in natural atmosphere seems to be better than the quick drying by a hot air stream in an oven. The film should be removed from the glass plate after complete drying-up of the gel.

\section{Detection of Isozyme Bands}

To visualize the enzyme activity as colored band(s), a staining solution (namely, reaction mixture) should be prepared. According to our experience, it is preferable to make a staining solution when the buffer front reaches the $4 \mathrm{~cm}$ mark during the electrophoretic run. The following reaction mixtures have been used for various enzymes in routine works: 
Lactate dehydrogenase (LDH) EG 1.1.1.27

D,L-Sodium lactate $(60 \%$ in water $)$

$2 \mathrm{ml}$

Distilled water

$25 \mathrm{ml}$

Nitroblue tetrazolium (NBT)

$25 \mathrm{mg}$

$0.2 \mathrm{M}$ Phosphate buffer, $\mathrm{pH} 7.4$

$25 \mathrm{ml}$

Nicotinamide adenine dinucleotide (NAD)

$40 \mathrm{mg}$

Phenazine methosulfate (PMS)

$0.5-1 \mathrm{mg}$

At first, put the substrate (sodium lactate) into a staining container. Dissolve NBT in water using a $50 \mathrm{ml}$ beaker, and after mixing well, the buffer solution should be added. (The final concentration of the buffer becomes $0.1 \mathrm{M}$, but if we use $50 \mathrm{ml}$ of the $0.1 \mathrm{M}$ buffer directly to dissolve NBT it may take a much longer time). Then pour the solution into the staining container. Just before the termination of an electrophoretic run, add the co-enzyme NAD to the solution in staining container. Remove the gel from the glass plate, put it into the reaction mixture, and incubate at $37^{\circ} \mathrm{C}$ for $5-10$ min. During this period, PMS can be dissolved into $2-3 \mathrm{ml}$ of distilled water. Then add this into the staining container. Shake the container gently in order that both sides of the gel will make good contact with the reaction mixture. Still continue the incubation, then after fully developing color, wash well the gel in large volumes of water until the yellow background color disappears.

Although Steiner \& Joslyn (1979) did not include LDH in their useful paper, detection of LDH bands in acrylamide gel is now not so difficult in larval, pupal, and adult stages as shown by Tsukamoto (1982). In the present paper, $\mathrm{KCN}$ and $\mathrm{MgCl}_{2}$ have been omitted from the previous reaction mixture.

Malate dehydrogenase (MDH) EC 1.1.1.37

$\begin{array}{lc}\text { Distilled water } & 25 \mathrm{ml} \\ \text { D,L-Disodium malate } & 300 \mathrm{mg} \\ \text { NBT } & 25 \mathrm{mg} \\ 0.2 \mathrm{M} \mathrm{Phosphate} \mathrm{buffer,} \mathrm{pH} 7.4 & 25 \mathrm{ml} \\ 10 \% \mathrm{MgCl}_{2} & 2-3 \mathrm{drops} \\ \mathrm{NAD} & 40 \mathrm{mg} \\ \text { PMS } & 0.5-1 \mathrm{mg}\end{array}$

Detection itself of $\mathrm{MDH}$ activity in a gel plate at $37^{\circ} \mathrm{C}$ is not difficult but the bands detected are usually very dull and broad, whereas malic enzyme, which will be mentioned below, shows a clear and narrow band in many mosquito species. 
Malic enzyme (ME) EC 1. 1. 1.40

Except for replacing co-enzyme NAD by NADP, the same reaction mixture just mentioned above can also be used for staining ME band.

Leucine aminopeptidase (LAP, Leucyl naphthyl amidase) EG 3.4.1.1

$\begin{array}{ll}\text { Distilled water } & 25 \mathrm{ml} \\ \text { L-Leucyl } \beta \text {-naphthylamide HGl salt } & 30 \mathrm{mg} \\ 0.2 \mathrm{M} \text { Phosphate buffer, } \mathrm{pH} 7.4 & 25 \mathrm{ml}\end{array}$

Dissolve the substrate completely with distilled water in a staining container. At the end of the electrophoretic run, pour the buffer into the container and quickly mix it with the substrate solution.

Put the gel into the reaction mixture and keep the container at room temperature $\left(20-30^{\circ} \mathrm{C}\right)$ for about $10 \mathrm{~min}$. During this incubation period the gel should be gently shaken occasionally, and the following staining solution should be prepared:
$0.2 \mathrm{M} \mathrm{KH}_{2} \mathrm{PO}_{4}$
$20 \mathrm{ml}$
Fast Garnet GBC salt
$35 \mathrm{mg}$

If necessary, filtrate the solution. After finishing the $10 \mathrm{~min}$ incubation, pour the staining solution into the container, and continue the incubation at room temperature for about 20-40 min until full development of the red color bands. Fill the staining container with water to overflowing to remove dirty floating materials. Then discard the solution, and wash the gel with large volumes of water with occasional change or wash in slow running water for $1-3 \mathrm{hr}$. Both $\mathrm{CoCl}_{2}$ and $\mathrm{KCN}$ have been omitted this time from the previous reaction mixture. When the substrate L-leucyl $\beta$-naphthylamide is replaced by L-alanyl $\beta$-naphthylamide, almost the same isozyme patterns will be obtained as those of LAP. Thus, the so-called "LAP" should not be considered to be specific to leucine moiety alone but should be considered to be non-specific aminopeptidases (unpublished data).

Non-specific esterases (Est) EG 3.1.1.1

The chemicals used for Est detection are very sensitive to light, and hence all the procedures should be done under dark conditions, otherwise background color may become too dark. Any dark and acetone-proof container, such as a stainless steel or duralumin box with cover, can be used for staining a gel.

1) Substrate solution

$\alpha$-Naphthyl acetate

$40 \mathrm{mg}$

Acetone

$4 \mathrm{ml}$ 
Dissolve the substrate with acetone within a small dark bottle sealed by an airtight screw cap.

2) Washing buffer solution

$$
0.1 \text { M Phosphate buffer, } \mathrm{pH} 6.8
$$

$50 \mathrm{ml}$

At the end of the electrophoresis, wash the gel in this buffer solution, which was previously put in an ice bath, for $5 \mathrm{~min}$ to reduce $\mathrm{pH}$ value of the gel.

3) Incubating buffer solution

$$
0.1 \text { M Phosphate buffer, } \mathrm{pH} 6.8 \quad 50 \mathrm{ml}
$$

Discard the washing buffer solution and replace with this fresh buffer solution. Add the substrate-acetone solution quickly into the stainless container, followed by immediate covering of the container. Incubate the container at room temperature $\left(20-30^{\circ} \mathrm{C}\right)$ for about $10 \mathrm{~min}$ with occasional shakes. During the incubation period, the following staining solution should be prepared:

4) Staining solution

Distilled water

$20 \mathrm{ml}$

Fast Blue B (or BB, RR, etc.) salt

$30 \mathrm{mg}$

0.2 M Phosphate buffer, $\mathrm{pH} 6.8$

$20 \mathrm{ml}$

At first completely dissolve the chemical in distilled water, then dilute with an equal volume of the buffer, thus the final concentration of the buffer will become $0.1 \mathrm{M}$. If necessary, filtrate the solution. At the end of $10 \mathrm{~min}$ incubation, pour the staining solution into the container quickly, and continue the incubation. Gentle and occasional shakes of the container will prevent adhesion of the gel onto the inner surface of the container. After quick confirmation of enough color development of the gel, discard the staining solution and wash the gel with several quick changes of water. Add a large amount of water into the container still under dark conditions. Several changes of washing water may be necessary to remove the stain completely from the gel, otherwise the gel may become darker later. After these washings the gel can be expose to light.

Instead of $\alpha$-naphthyl acetate, $\beta$-naphthyl acetate or a mixture of both $\alpha$-and $\beta$ isomers can also be used, although $\alpha$-isomer seems to give rise to a more intense color in isozyme bands than $\beta$-isomer.

Alkaline phosphatase (AlP) EG 3.1.3.1

$$
\begin{array}{lc}
\alpha \text {-Naphthyl phosphate, } \mathrm{Na} \text { salt } & 40 \mathrm{mg} \\
0.1 \mathrm{M} \text { Tris-HCl buffer, } \mathrm{pH} 8.5 & 50 \mathrm{ml} \\
10 \% \mathrm{MgCl}_{2} & 2 \text { drops }
\end{array}
$$


Incubate a gel for $15 \mathrm{~min}$ at $37^{\circ} \mathrm{C}$ in the substrate solution. During this incubation period, the following staining solution should be prepared:

$$
\begin{array}{ll}
\text { Fast Blue B (or BB, RR, etc.) salt } & 40 \mathrm{mg} \\
0.1 \mathrm{M} \text { Tris-HCl buffer, } \mathrm{pH} 8.5 & 20 \mathrm{ml}
\end{array}
$$

Add this solution into the container, then continue the incubation from about $30 \mathrm{~min}$ to 2 hours at $37^{\circ} \mathrm{C}$. After full development of the color bands, the gel should be washed completely in water. Some mosquito larvae show very strong activity band(s) but in many species the enzyme activity is not high enough to show a clear band.

Acid phosphatase (AcP) EG 3. 1.3.2

Except for acidifying the gel prior to reaction, similar techniques can be used for detecting acid phosphatase bands.

After electrophoresis, wash the gel with the following buffer for $15 \mathrm{~min}$ in an ice bath:

$$
0.2 \mathrm{M} \text { Acetate buffer, } \mathrm{pH} 4.6
$$

$50 \mathrm{ml}$

Then prepare the reaction mixture as follows:

$\begin{array}{ll}0.2 \mathrm{M} \text { Acetate buffer, } \mathrm{pH} 4.6 & 25 \mathrm{ml} \\ \text { Disodium } \alpha \text {-naphthyl phosphate } & 50 \mathrm{mg}\end{array}$

After a $30 \mathrm{~min}$ incubation at $37^{\circ} \mathrm{C}$, add the following staining solution:

$$
\begin{array}{ll}
0.2 \mathrm{M} \text { Acetate buffer, } \mathrm{pH} 4.6 & 10 \mathrm{ml} \\
\text { Fast Blue B (or BB, RR, etc.) salt } & 30 \mathrm{mg}
\end{array}
$$

Continue the incubation until the color bands are fully developed. The color intensity of bands is usually not very strong in many species.

\section{General Remarks}

The method described here was based on our actual experiences with successful results both in the laboratory and under non-laboratory environments of tropical areas wherever ice is available. It requires a smaller space, smaller equipments, and hence a less expensive running cost, but it produces better results. Therefore, it is applicable for any field work on mosquito larvae. But this does not mean that this method is the best. Further modifications should be tried by many workers using their own materials. Gel concentration is one of the most critical factors in obtaining reproducible results, especially when the absolute mobility of an isozyme band is considered. Therefore, the importance of accurate measurements of chemicals should always be recognized in preparation of stock solutions. Co-enzyme NAD and NADP are usually kept in a freezer under a laboratory circumstance but they can be effectively used 
for at least up to 3 months even at tropical room temperature when the chemicals are kept with a desiccating agent in an airtight can.

\section{Acknowledgements}

I would like to express my sincere thanks to Miss Hitomi Kamikubo for excellent laboratory assistance especially in determining various electrophoretic conditions. I am also grateful to Mr. Wej Choochote and Miss Aungkana Rajbandit, Department of Parasitology, Faculty of Medicine, Chiang Mai University, Thailand, for their help in preparing a part of the original manuscript which made me decide to prepare this paper in more detail. The electrophoretic apparatus reported here was made by Mr. M. Tanaka, to whom I owe thanks for his useful suggestions and advice.

\section{References Cited}

Ogita, Z. (1965) : Polyacrylamide gel electrophoresis. I. Metab. Dis., 2: 331-334. (in Japanese)

Shaw, C. R. \& Prasad, R. (1970) : Starch gel electrophoresis of enzymes - A compilation of recipes. Biochem. Genet., 4: 297-320.

Steiner, W. W. M. \& Joslyn, D. J. (1979) : Electrophoretic techniques for the genetic study of mosquitoes. Mosq. News, 39: 35-54.

Tsukamoto, M. (1974): Differential detection of soluble enzymes specific to a rodent malaria parasite, Plasmodium, berghei, by electrophoresis on polyacrylamide gels. Trop. Med., 16: 55-69.

Tsukamoto, M. (1982): Disclosure of hidden isozyme bands of lactate dehydrogenase in mosquito larvae. J. UOEH, 4: 301-311.

蚊幼虫のアイソザイム比較に用いられた電気泳動法手技

塚 本 增 久

産業医科大学医動物学教室

要 旨： 蚊の系統分類学的関係をアイソザイムの見地から生化学的に検討するために，ポリアクリ ルアミド平板ゲルを用いて電気泳動像の解明を試みている。そのため泳動の基本となる諸 条件を検討し，簡単で再現性が高く良い分離が得られるように工夫改良を重枕たので，そ の手法の詳細を述べ今後の研究に便ならしめた。ここ机により日本での研究室のみならず, 材料は豊富だが電気や水道のない東南アジアの辺地でさえも，承が入手できるところでは 携帯用発電機上小型水中ポンプを用い机ば，採集された幼虫材料を現地ですぐに電気泳動 にかけることができるようになった。

J. UOEH（産業医大誌），6（2 ）: 193-204 (1984) 